\title{
Type II, but not type I, cGMP-dependent protein kinase reverses bFGF-induced proliferation and migration of $\mathrm{U} 251$ human glioma cells
}

\author{
ZHI-HONG CAO $^{2 *}$, YAN TAO ${ }^{1 *}$, JIAN-RONG SANG ${ }^{1}$, YIN-JIE GU $^{2}$, XIU-JUAN BIAN $^{3}$ and YONG-CHANG CHEN ${ }^{1}$ \\ ${ }^{1}$ School of Medical Science and Laboratory Medicine, Jiangsu University, Zhenjiang, Jiangsu 212013; \\ ${ }^{2}$ Department of Intensive Care Unit, Affiliated Hospital of Jiangsu University, Yixing, Jiangsu 214200; \\ ${ }^{3}$ Department of Respiratory Diseases, Affiliated Hospital of Jiangsu University, Zhenjiang, Jiangsu 212001, P.R. China
}

Received October 24, 2012; Accepted January 29, 2013

DOI: $10.3892 / \mathrm{mmr} .2013 .1319$

\begin{abstract}
Previous data have shown that the type II cGMP-dependent protein kinase (PKG II) inhibits the EGF-induced MAPK signaling pathway. In order to thoroughly investigate $\mathrm{PKG}$, it is necessary to elucidate the function of another type of PKG, PKG I. The aim of this study was to investigate the possible inhibitory effect of PKG II and PKG I activity on the basic fibroblast growth factor (bFGF)-induced proliferation and migration of U251 human glioma cells and the possible underlying mechanisms. U251 cells were infected with adenoviral constructs encoding cDNA of PKG I (Ad-PKG I) or PKG II (Ad-PKG II) to increase the expression levels of PKG I or PKG II and then treated with 8-Br-cGMP and 8-pCPT-cGMP, respectively, to activate the enzyme. An MTT assay was used to detect the proliferation of the U251 cells. The migration of the U251 cells was analyzed using a Transwell migration assay. Western blot analysis was used to detect the phosphorylation/activation of the fibroblast growth factor receptor (FGFR), MEK and ERK and the nuclear distribution of p-ERK. The results showed that bFGF treatment increased the proliferation and migration of U251 cells, accompanied by increased phosphorylation of FGFR, MEK and ERK. Furthermore, the nuclear distribution of $\mathrm{p}-\mathrm{ERK}$ increased following bFGF treatment. Increasing the activity of PKG II through infection with Ad-PKG II and stimulation with 8-pCPT-cGMP significantly attenuated the aforementioned effects of the bFGF treatment, while increased PKG I activity did not inhibit the effects of bFGF treatment. These data suggest that increased
\end{abstract}

Correspondence to: Yan Tao, School of Medical Science and Laboratory Medicine, Jiangsu University, 301 Xuefu Road, Zhenjiang, Jiangsu 212013, P.R. China

E-mail: yantao1981@126.com

*Contributed equally

Key words: type II cGMP-dependent protein kinase, MAPK/ERK, proliferation, migration, human glioma cells
PKG II activity attenuates bFGF-induced proliferation and migration by inhibiting the MAPK/ERK signaling pathway, whereas PKG I does not.

\section{Introduction}

Basic fibroblast growth factor (bFGF) is a multifunctional growth factor involved in tumor development, including cell differentiation, cell growth, migration, angiogenesis and tumor formation (1-4). Its biological effects have been reported to be exerted mainly through interaction with its high-affinity receptor, fibroblast growth factor receptor 1 (FGFR1) (5-8). Narong and Leelawat (9) reported that bFGF enhances the migration of cholangiocarcinoma cells by the phosphorylation of MEK1/2. Results from previous studies have shown that bFGF signaling plays a key role in the development of cancer, including gastric, lung and endometrial cancer (10-12).

The cGMP-dependent protein kinases (PKGs) are serine/threonine kinases and include two types of PKGs, PKG I and PKG II $(13,14)$. PKG I is widely distributed within the body and its expression levels are lower in various tumor tissues. PKG II is more tissue-restricted and is characterized by reduced expression levels in many types of tumor cells (15). PKG I leads to decreased tumor growth and invasiveness in many types of cells, including cardiomyocytes, mesangial cells and neutrophils (16-19). PKG I has been identified to be a tumor suppressor (20). Previous studies suggest that PKG II has a role in the regulation of cell proliferation and apoptosis (21-24). Swartling et al (25) reported that PKG II inhibits the proliferation of human neuroglioma cells and that the inhibition was related to reductions in transcription factor Sox 9 expression levels and Akt phosphorylation. We have prevously observed that the expression and activity of PKG II in human gastric cancer cells were significantly lower compared with those in normal cells (26). Additionally, another study conducted in our laboratory demonstrated an inhibitory effect of PKG II on the proliferation of gastric cancer cells (27).

Previous studies have demonstrated the inhibitory effect of PKG on cell proliferation and the stimulatory effect of bFGF on cell proliferation and migration. However, whether PKG is able to attenuate the bFGF-induced effects on U251 
cells remains to be elucidated. The aim of this study was to determine the relationship between PKG and bFGF, and to investigate how PKG exerts its inhibitory effects.

\section{Materials and methods}

Cell line. The human glioma cell line U251 was provided by the Institute of Cell Biology (Shanghai, China).

Reagents. Antibodies against MEK and p-MEK (Ser217/221) were purchased from Cell Signaling Technology, Inc.(Danvers, MA, USA). Antibodies against ERK, p-ERK1/2 and actin were from Santa Cruz Biotechnology, Inc. (Santa Cruz, CA, USA). Antibodies against p-ERK (Thr202/Tyr204), p-FGFR (Y154), FGFR and $\beta$-actin were from Bioworld Technology Co., Ltd. (St. Louis Park, MN, USA). Horseradish peroxidase (HRP)-conjugated secondary antibodies were from Jackson ImmunoResearch Laboratories, Inc. (West Grove, PA, USA). The cellular permeable cGMP analog 8-pCPT-cGMP and 8-Br-cGMP were from Calbiochem (San Diego, CA, USA). Electrochemiluminescence (ECL) reagent was from Millipore (Billerica, MA, USA). Dulbecco's modified Eagle's medium (DMEM) and newborn calf serum (NBCS) were from Gibco (Grand Island, NY, USA).

MTT assay. U251 cells $\left(0.5-1 \times 10^{3}\right)$ were plated on 96-well plates in $150 \mu \mathrm{l}$ medium. The cells were infected with Ad-Lacz, Ad-PKG I or Ad-PKG II for $24 \mathrm{~h}$ to establish Ad-Lacz+bFGF, Ad-PKG I+bFGF and Ad-PKG II+bFGF groups. In the Ad-PKG I+bFGF and Ad-PKG II+bFGF groups, $250 \mu \mathrm{M} 8$ 8-Br-cGMP and $250 \mu \mathrm{M} 8$-pCPT-cGMP were added to activate PKG I and PKG II, respectively. Then, the cells were incubated with bFGF $(100 \mathrm{ng} / \mathrm{ml})$ for $12 \mathrm{~h}$. The cultured cells were washed with phosphate-buffered saline (PBS), treated with $20 \mu 1$ MTT $(0.5 \mathrm{mg} / \mathrm{ml})$ and then incubated at $37^{\circ} \mathrm{C}$ for $1 \mathrm{~h}$. The medium was removed and $100 \mu 1$ dimethylsulfoxide (DMSO) was added to each well. The absorbance was determined at $570 \mathrm{~nm}$ using a microplate reader. All the experiments were performed in triplicate.

Cell migration assay. The migration of the $\mathrm{U} 251$ human glioma cells was investigated using a chamber with $8-\mu \mathrm{m}$ pore filters (Transwell, 24-well cell culture; Coster, Boston, MA, USA). U251 cells were infected with Ad-Lacz, Ad-PKG I or Ad-PKG II for $48 \mathrm{~h}$ to establish Ad-Lacz+bFGF, Ad-PKG I+bFGF and Ad-PKG II+bFGF groups. The cells were serum starved overnight and, in the Ad-PKG I+bFGF and Ad-PKG II+bFGF groups, $250 \mu \mathrm{M}$ 8-Br-cGMP and $250 \mu \mathrm{M}$ 8-pCPT-cGMP were added to activate PKG I and PKG II, respectively. The cells were then incubated with bFGF $(100 \mathrm{ng} / \mathrm{ml})$ for $12 \mathrm{~h}$ at $37^{\circ} \mathrm{C}$. Following incubation, the filters were fixed and stained with hematoxylin and the cells were counted in five random high-power fields under a light microscope.

Nuclear protein preparation. According to the method described by Chen et al (28), cells growing on $100-\mathrm{mm}$ plates were harvested in HEM buffer (10 mM HEPES $\mathrm{pH} 7.5,2 \mathrm{mM}$ EDTA, $1 \mathrm{mM} \mathrm{MgCl} 2$ ) and homogenized with an ultrasonic homogenizer. The homogenate was centrifuged at $500 \mathrm{x} \mathrm{g}$ at $4^{\circ} \mathrm{C}$ for $5 \mathrm{~min}$ to obtain the nuclei of the cells. Pre-heated

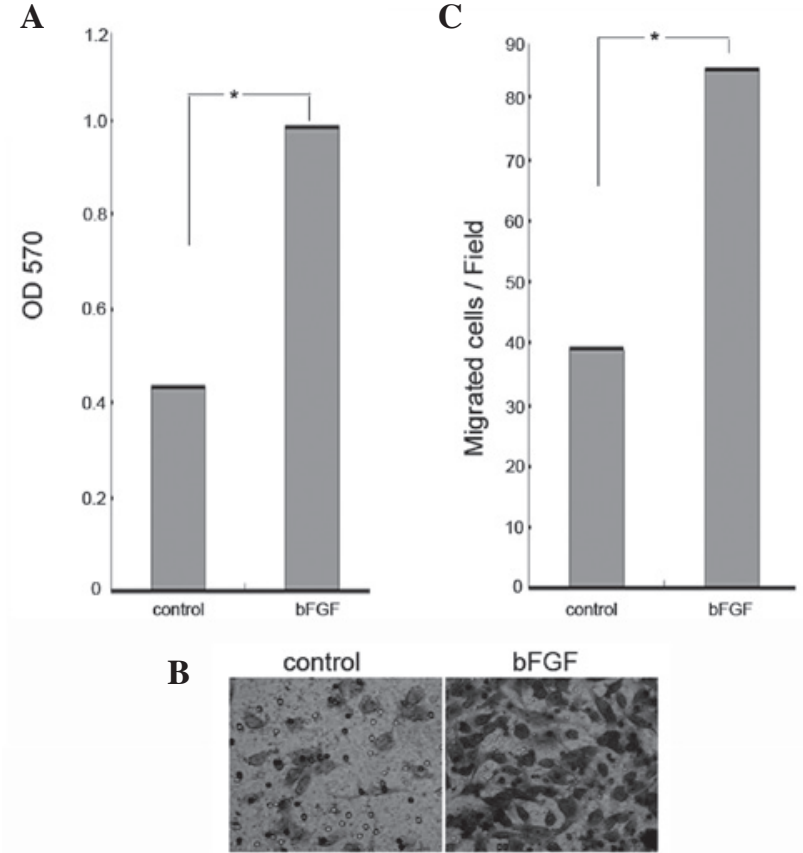

Figure 1. bFGF enhances the proliferation and migration of U251 human glioma cells. (A) An MTT assay was used to detect the proliferation of U251 cells. Compared with the control, cell growth was markedly increased following treatment with $100 \mathrm{ng} / \mathrm{ml}$ bFGF for $48 \mathrm{~h}$. A Transwell migration assay was used to measure the migration of U251 cells. (B and C) Representative figures of cell migration in control and bFGF-treated U251 cells. Compared with the control, cell migration was markedly increased following treatment with $100 \mathrm{ng} / \mathrm{ml} \mathrm{bFGF}$ for $12 \mathrm{~h}$. The means of five independent experiments \pm standard error are shown. ${ }^{*} \mathrm{P}<0.05$. bFGF, basic fibroblast growth factor.

SDS-PAGE loading buffer was added to the pellet and boiled for $5 \mathrm{~min}$ to obtain the nuclear proteins.

Western blot analysis. Sample proteins were separated on SDS-PAGE gels and blotted onto polyvinyl difluoride (PVDF) membranes. The PVDF membranes were blocked with $3 \%(\mathrm{w} / \mathrm{v})$ bovine serum albumin (BSA) in TBS-T for $1 \mathrm{~h}$ at room temperature. Incubation with the primary antibody was conducted at $4^{\circ} \mathrm{C}$ overnight, and incubation with the secondary antibody was conducted at room temperature for $1 \mathrm{~h}$, with three washes following each incubation. ECL reagents were used to show the positive bands on the membrane. The bands were detected using Typhoon 9400 (GE Healthcare, Piscataway, NJ, USA).

Statistical analysis. Values are expressed as the means $\pm \mathrm{SE}$ $\left(\mathrm{n}=5 ;{ }^{*} \mathrm{P}<0.05\right)$. The Student's t-test was used for comparisons of two sample means. A P-value of $<0.05(\mathrm{P}<0.05)$ was considered to indicate a statistically significant difference.

\section{Results}

bFGF promotes the proliferation and migration of U251 human glioma cells. bFGF has been observed to stimulate cancer cell proliferation (29). In the present study, an MTT assay was used to determine whether bFGF had any effect on the proliferation of U251 human glioma cells. The U251 cells were treated with $\mathrm{bFGF}$ at a concentration of $100 \mathrm{ng} / \mathrm{ml}$ for 


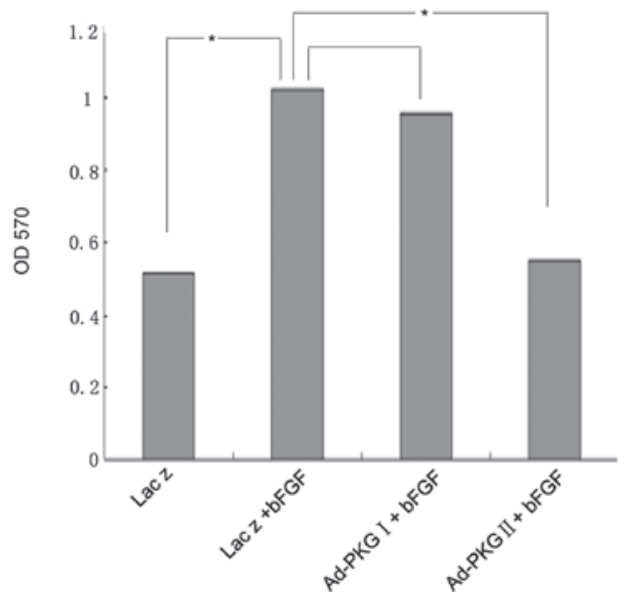

Figure 2. PKG II, but not PKG I, reverses bFGF-induced proliferation of U251 human glioma cells. An MTT assay was used to detect the proliferation of U251 cells. U251 cells were infected with Ad-Lacz, Ad-PKG I or Ad-PKG II for $24 \mathrm{~h}$ to establish Ad-Lacz+bFGF, Ad-PKG I+bFGF and Ad-PKG II+bFGF groups. The cells were serum starved overnight and, in the Ad-PKG I+bFGF and Ad-PKG II+bFGF groups, $250 \mu \mathrm{M} 8$-Br-cGMP and $250 \mu \mathrm{M} 8$-pCPT-cGMP were added to activate PKG I and PKG II, respectively. The cells were then incubated with bFGF (100 $\mathrm{ng} / \mathrm{ml})$ for $48 \mathrm{~h}$. The means of five independent experiments \pm standard error are shown. ${ }^{*} \mathrm{P}<0.05$ PKG, cGMP-dependent protein kinase; bFGF, basic fibroblast growth factor.

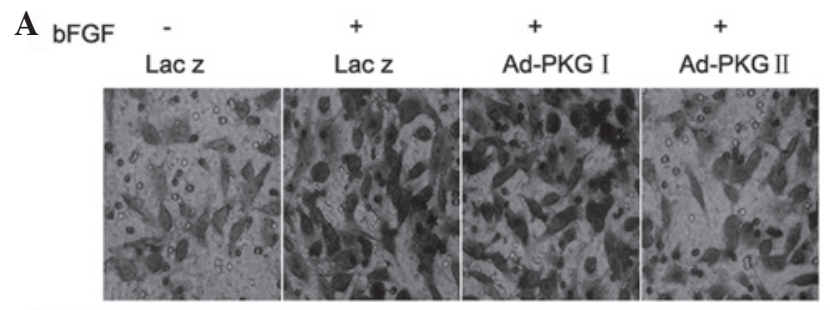

B

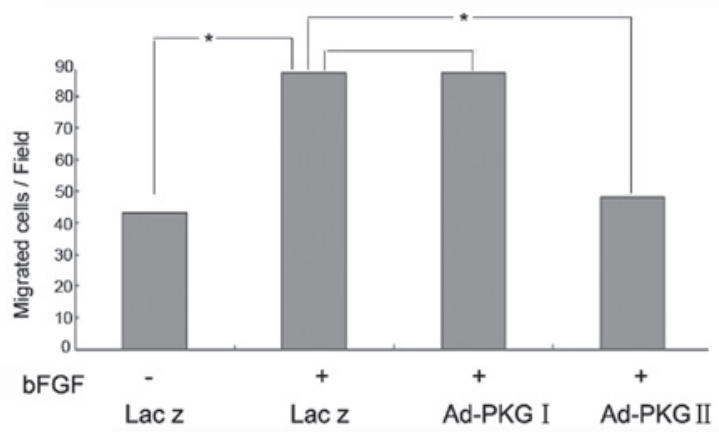

Figure 3. PKG II, but not PKG I, prevents bFGF-induced migration of U251 human glioma cells. (A and B) A Transwell migration assay was used to investigate the migration of U251 cells. U251 cells were infected with Ad-Lacz, Ad-PKG I or Ad-PKG II for $48 \mathrm{~h}$ to establish Ad-Lacz+bFGF, Ad-PKG I+bFGF and Ad-PKG II+bFGF groups. The cells were serum starved overnight and, in the Ad-PKG I+bFGF and Ad-PKG II+bFGF groups, $250 \mu \mathrm{M} 8$-Br-cGMP and $250 \mu \mathrm{M} 8$-pCPT-cGMP were added to activate PKG I and PKG II, respectively. Then, the cells were incubated with bFGF $(100 \mathrm{ng} / \mathrm{ml})$ for $12 \mathrm{~h}$. The means of five independent experiments \pm standard error are shown. " $\mathrm{P}<0.05$. PKG, cGMP-dependent protein kinase; bFGF, basic fibroblast growth factor.

$48 \mathrm{~h}$. The results showed that there was a significant increase in the proliferation of cells treated with bFGF (Fig. 1A). Recent findings have shown that bFGF stimulates cancer cell migration (30). In order to determine the effects of bFGF on the migration of $\mathrm{U} 251$ cells, the cells were treated with bFGF

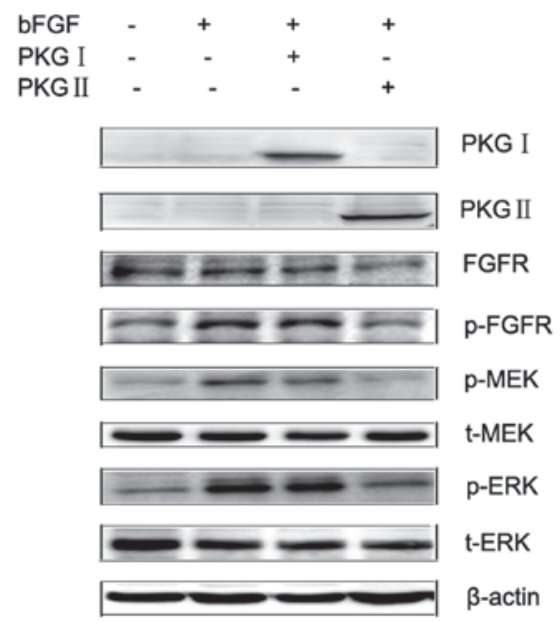

Figure 4. PKG II, but not PKG I, attenuated the bFGF-induced activation of the MAPK/ERK pathway in U251 human glioma cells. U251 cells were infected with Ad-Lacz, Ad-PKG I or Ad-PKG II for $48 \mathrm{~h}$ to establish Ad-Lacz+bFGF, Ad-PKG I+bFGF and Ad-PKG II+bFGF groups. The cells were serum starved overnight and, in the Ad-PKG I+bFGF and Ad-PKG II+bFGF groups, $250 \mu \mathrm{M} 8$-Br-cGMP and $250 \mu \mathrm{M}$ 8-pCPT-cGMP were added to activate PKG I and PKG II, respectively. Then, the cells were incubated with bFGF $(100 \mathrm{ng} / \mathrm{ml})$ for $15 \mathrm{~min}$. Whole cells were harvested and lysed as described in Materials and methods and cell lysates were subjected to western blot analysis. Results showed that infection with Ad-PKG I and Ad-PKG II caused a marked increase of PKG I and PKG II expression levels, respectively. bFGF treatment induced a significant increase of FGFR, MEK and ERK phosphorylation. Infection with Ad-PKG II and stimulation with 8-pCPT-cGMP, but not Ad-PKG I+8-Br-cGMP treatment, efficiently inhibited the bFGF-induced phosphorylation of FGFR, MEK and ERK. The means of five independent experiments \pm standard error are shown. PKG, cGMP-dependent protein kinase; bFGF, basic fibroblast growth factor; FGFR, fibroblast growth factor receptor.

at a concentration of $100 \mathrm{ng} / \mathrm{ml}$ for $12 \mathrm{~h}$ and then examined using a cell migration assay. Compared with the control, the percentage of U251 cell migration was significantly increased when the cells were treated with $100 \mathrm{ng} / \mathrm{ml}$ of $\mathrm{bFGF}(\mathrm{P}<0.0051)$ (Fig. 1B). This demonstrates that bFGF increases both the proliferation and migration of U251 human glioma cells.

PKG II, but not PKG I, prevents the bFGF-induced proliferation of U251 human glioma cells. In the present study, we demonstrated that bFGF stimulates the proliferation of U251 human glioma cells. Since our previous study demonstrated that PKG II inhibits the proliferation of gastric cancer cells, the aim of the current study was to investigate whether PKG II and PKG I are able to attenuate the bFGF-induced proliferation of U251 cells. Compared with U251 cells treated with bFGF at a concentration of $100 \mathrm{ng} / \mathrm{ml}$ alone, cells infected with Ad-PKG II and stimulated with 8-pCPT-cGMP prior to treatment with bFGF, showed a reduction in proliferation, while there was no obvious change when the cells were infected with Ad-PKG I and stimulated with 8-Br-cGMP (Fig. 2). This indicates that PKG II, but not PKG I, inhibits the bFGF-induced proliferation of $\mathrm{U} 251$ cells.

PKG II, but not PKG I, prevents the bFGF-induced migration of U251 human glioma cells. In the present study, it was demonstrated that bFGF enhances the migration of U251 human glioma cells. There has been no data demonstrating 


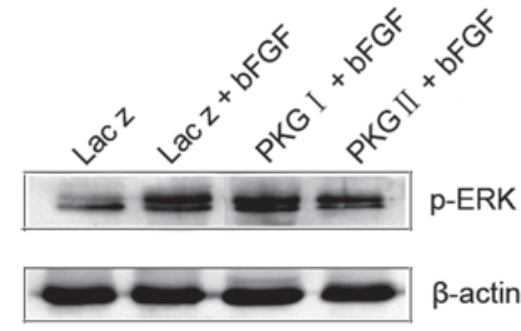

Figure 5. PKG II, but not PKG I, reverses the bFGF-triggered nuclear distribution of p-ERK in U251 human glioma cells. U251 cells were infected with Ad-Lacz, Ad-PKG I or Ad-PKG II for $48 \mathrm{~h}$ to establish Ad-Lacz+bFGF, Ad-PKG I+bFGF and Ad-PKG II+bFGF groups. The cells were serum starved overnight and, in the Ad-PKG I+bFGF and Ad-PKG II+bFGF groups, $250 \mu \mathrm{M} \mathrm{8-Br-cGMP}$ and $250 \mu \mathrm{M} 8$-pCPT-cGMP were added to activate PKG I and PKG II, respectively. The cells were then incubated with bFGF $(100 \mathrm{ng} / \mathrm{ml})$ for $30 \mathrm{~min}$. Nuclear cell lysate was prepared as described in Materials and methods and subjected to western blot analysis. The results indicated that bFGF treatment induced a significant increase in the expression of p-ERK in the nucleus. Infection with Ad-PKG II and stimulation with 8-pCPT-cGMP, but not Ad-PKG I+8-Br-cGMP treatment, efficiently inhibited the bFGF-induced nuclear distribution of p-ERK. The means of five independent experiments \pm standard error are shown. PKG, cGMP-dependent protein kinase; $\mathrm{bFGF}$, basic fibroblast growth factor.

the effect of PKG on the migration of cancer cells to date. In the present study, we investigated whether PKG was able to prevent the bFGF-induced migration of U251 cells. Compared with U251 cells treated with bFGF at a concentration of $100 \mathrm{ng} / \mathrm{ml}$ alone, cells infected with Ad-PKG II and stimulated with 8-pCPT-cGMP prior to treatment with bFGF, showed a decreased migratory activity, while there was no clear change of the cells infected with Ad-PKG I and stimulated with 8-Br-cGMP (Fig. 3). This indicates that PKG II, but not PKG I, inhibits the bFGF-induced migration of U251 cells.

PKG II, but not PKG I, prevents the bFGF-induced activation of the MAPK/ERK signaling pathway in U251 human glioma cells. FGF receptors activate several intracellular signaling pathways, including the MAP kinase pathway (31-33). Western blot analysis was used to detect FGFR phosphorylation. MEK1 and MEK2 are members of the dual specificity protein kinase family, which act as MAPK or ERK kinases. Phosphorylation at both Thr202/Tyr204 residues of ERK1 and Thr185/Tyr187 residues of ERK2 is required for full enzymatic activation. Western blot analysis was used to detect MEK and ERK phosphorylation. The results indicated that treatment with bFGF alone at a concentration of $100 \mathrm{ng} / \mathrm{ml}$, increased the phosphorylation levels of FGFR, MEK and ERK. The increased phosphorylation was inhibited by pre-infecting the cells with Ad-PKG II and stimulating the enzyme with 8-pCPT-cGMP, while no significant inhibitory effect was achieved by pre-infecting the cells with Ad-PKG I and stimulating the enzyme with 8 -Br-cGMP. These results demonstrate that increased PKG II activity prevents the bFGF-induced phosphorylation of FGFR, MEK and ERK in U251 human glioma cells but increased PKG I activity does not (Fig. 4). Furthermore, we investigated the effect of PKG on the bFGF-induced nuclear translocation of p-ERK. The results showed that bFGF stimulated the nuclear distribution of p-ERK, and that the stimulatory effect was inhibited by pre-infecting the cells with Ad-PKG II and stimulating the enzyme with 8-pCPT-cGMP, while pre-infecting the cells with Ad-PKG I and stimulating the enzyme with 8-Br-cGMP had no inhibitory effect (Fig. 5). The results indicate that increased PKG II activity attenuated the bFGF-triggered p-ERK nuclear distribution whereas increased PKG I activity did not.

\section{Discussion}

The growth of solid tumors depends on the occurrence of neovascularization. bFGF is an important angiogenic factor, widely distributed in neoplastic tissues (34). Numerous angiogenic peptides have been identified and their effects on tumor vascularity have also been identified (35-38). FGF receptors activate several intracellular signaling pathways, including MAP kinase pathways. MAP kinase pathways have been identified as the ERK/MAP kinase pathway, the JNK/SAPK pathway and the p38 pathway $(39,40)$. These three pathways may be activated by different growth factors and mediate several cellular events, including cell differentiation, stress responses and growth. However, the activation of each type of MAP kinase mainly depends on the type of the stimulus and the cells.

PKG plays important regulatory roles in diverse processes in many cell types $(15,41,42)$. Its expression is differently regulated in tumors and in normal tissue $(14,43,44)$. In mammalian cells, two different genes encode type I and II PKGs (45). PKG I includes two isoforms, PKG I $\alpha$ and PKG I $\beta$, which differ in the first $\sim 100$ amino acids (46). PKG I has been recognized as a tumor suppressor. PKG II is membrane-anchored and is present at low levels in several types of human cancer cells (47). Previous data have indicated that PKG II is related to cell proliferation and apoptosis $(21,22)$. We have also found that PKG II attenuates the EGF-induced proliferation and apoptosis of gastric cancer cells $(48,49)$. There has been no data showing the relationship between PKG and migration. In the present study, the exact stimulative effects of bFGF on the proliferation and migration of U251 human glioma cells was confirmed. Consequently, we performed further experiments to investigate whether PKG I or PKG II exerted inhibitory effects on the bFGF-induced proliferation and migration of human glioma cells, and the possible underlying mechanism.

In the present study, the PKG I-selective cGMP analog 8-Br-cGMP and the PKG II-selective cGMP analog 8-pCPT-cGMP were applied to increase PKG I or PKG II activity when cells were infected with Ad-PKG I or Ad-PKG II, respectively. After confirming the effects of bFGF on the proliferation and migration of U251 human glioma cells, we analyzed the effects of PKG I and PKG II on bFGF-stimulated cell proliferation and migration. Compared with treatment with bFGF alone, increased PKG II activity clearly attenuated bFGF-induced proliferation and migration, while increased PKG I activity had no effect. Then, we investigated the inhibitory effects of PKG I and PKG II on the bFGF-induced phosphorylation of FGFR, MEK and ERK. It was found that increased PKG II, but not PKG I, activity was able to attenuate bFGF-induced phosphorylation. Furthermore, the inhibitory effects of PKG I and PKG II on the bFGF-induced nuclear distribution of $\mathrm{p}$-ERK were detected. The results obtained showed that increased PKG II, but not PKG I, activity was able to attenuate bFGF-induced p-ERK nuclear distribution. 
In this study it was shown that increased PKG II, but not PKG I, activity inhibits bFGF-stimulated cell proliferation and migration, bFGF-induced FGFR, MEK and ERK phosphorylation and bFGF-induced p-ERK nuclear distribution in U251 human glioma cells. In conclusion, the inhibitory effects of PKG II on bFGF-induced cell proliferation and migration were mainly exerted by blocking the MAPK/ERK signaling pathway.

\section{Acknowledgements}

This study was supported by the National Natural Science Foundation of China (nos. 31100974 and 81001100) and the Specialized Research Fund for Senior Personnel Program of Jiangsu University (no. 11JDG032).

\section{References}

1. Ribatti D, Vacca A, Rusnati M and Presta M: The discovery of basic fibroblast growth factor/fibroblast growth factor-2 and its role in haematological malignancies. Cytokine Growth Factor Rev 18: 327-334, 2007.

2. Shi YH, Bingle L, Gong LH, Wang YX, Corke KP and Fang WG: Basic FGF augments hypoxia induced HIF-1-alpha expression and VEGF release in T47D breast cancer cells. Pathology 39: 396-400, 2007.

3. Smith JA, Madden T, Vijjeswarapu M and Newman RA: Inhibition of export of fibroblast growth factor-2 (FGF-2) from the prostate cancer cell lines PC3 and DU145 by Anvirzel and its cardiac glycoside component, oleandrin. Biochem Pharmacol 62 : 469-472, 2001.

4. Cronauer MV, Hittmair A, Eder IE, Hobisch A, Culig Z, Ramoner R, Zhang J, Bartsch G, Reissigl A, Radmayr C, Thurnher M and Klocker H: Basic fibroblast growth factor levels in cancer cells and in sera of patients suffering from proliferative disorders of the prostate. Prostate 31: 223-233, 1997.

5. Giehl KA, Nägele U, Volkenandt $M$ and Berking C: Protein expression of melanocyte growth factors (bFGF, SCF) and their receptors (FGFR-1, c-kit) in nevi and melanoma. J Cutan Pathol 34: 7-14, 2007.

6. Fortin D, Rom E, Sun H, Yayon A and Bansal R: Distinct fibroblast growth factor (FGF)/FGF receptor signaling pairs initiate diverse cellular responses in the oligodendrocyte lineage. J Neurosci 25: 7470-7479, 2005.

7. Udayakumar TS, Klein RD, Maliner MS, Nagle RB and Bowden GT: Aberrant expression of fibroblast growth factor receptor-1 in prostate epithelial cells allows induction of promatrilysin expression by fibroblast growth factors. Int J Cancer 91: 187-192, 2001

8. Kamura S, Matsumoto Y, Fukushi JI, Fujiwara T, Iida K, Okada Y and Iwamoto Y: Basic fibroblast growth factor in the bone microenvironment enhances cell motility and invasion of Ewing's sarcoma family of tumours by activating the FGFR1-PI3K-Rac1 pathway. Br J Cancer 103: 370-381, 2010.

9. Narong $\mathrm{S}$ and Leelawat K: Basic fibroblast growth factor induces cholangiocarcinoma cell migration via activation of the MEK1/2 pathway. Oncol Lett 2: 821-825, 2011.

10. Zhang W, Chu YQ, Ye ZY, Zhao ZS and Tao HQ: Expression of hepatocyte growth factor and basic fibroblast growth factor as prognostic indicators in gastric cancer. Anat Rec (Hoboken) 292: $1114-1121,2009$.

11. Massabeau C, Rouquette I, Lauwers-Cances V, Mazières J, Bachaud JM, Armand JP, Delisle MB, Favre G, Toulas C and Cohen-Jonathan-Moyal E: Basic fibroblast growth factor-2/beta3 integrin expression profile: signature of local progression after chemoradiotherapy for patients with locally advanced non-small-cell lung cancer. Int J Radiat Oncol Biol Phys 75: 696-702, 2009.

12. Dai H, Zhao S, Xu L, Chen A and Dai S: Expression of Efp, VEGF and bFGF in normal, hyperplastic and malignant endometrial tissue. Oncol Rep 23: 795-799, 2010.

13. Orstavik S, Natarajan V, Tasken K, Jahnsen T and Sandberg M: Characterization of the human gene encoding the type I alpha and type I beta cGMP-dependent protein kinase (PRKG1). Genomics 42: 311-318, 1997.
14. Orstavik S, Solberg R, Tasken K, Nordahl M, Altherr MR, Hansson V, Jahnsen T and Sandberg M: Molecular cloning, cDNA structure, and chromosomal localization of the human type II cGMP-dependent protein kinase. Biochem Biophys Res Commun 220: 759-765, 1996.

15. Lincoln TM, Dey $\mathrm{N}$ and Sellak $\mathrm{H}$ : Invited review: cGMP-dependent protein kinase signaling mechanisms in smooth muscle: from the regulation of tone to gene expression. J Appl Physiol 91: 1421-1430, 2001.

16. Shimojo T, Hiroe M, Ishiyama S, Ito H, Nishikawa $T$ and Marumo F: Nitric oxide induces apoptotic death of cardiomyocytes via a cyclic-GMP-dependent pathway. Exp Cell Res 247: 38-47, 1999.

17. Segawa K, Minami K, Shiga Y, Shiraishi M, Sata T, Nakashima Y and Shigematsu A: Inhibitory effects of nicorandil on rat mesangial cell proliferation via the protein kinase $\mathrm{G}$ pathway. Nephron 87: 263-268, 2001

18. Loweth AC, Williams GT, Scarpello JH and Morgan NG: Evidence for the involvement of cGMP and protein kinase $\mathrm{G}$ in nitric oxide-induced apoptosis in the pancreatic B-cell line, HIT-T15. FEBS Lett 400: 285-288, 1997.

19. Brunetti M, Mascetra N, Manarini S, Martelli N, Cerletti C, Musiani P, Aiello FB and Evangelista V: Inhibition of cGMP-dependent protein kinases potently decreases neutrophil spontaneous apoptosis. Biochem Biophys Res Commun 297: 498-501, 2002.

20. Hou Y, Gupta N, Schoenlein P, Wong E, Martindale R, Ganapathy V and Browning D': An anti-tumor role for cGMP-dependent protein kinase. Cancer Lett 240: 60-68, 2006.

21. Cook AL and Haynes JM: Protein kinase G II-mediated proliferative effects in human cultured prostatic stromal cells. Cell Signal 16: 253-261, 2004.

22. Cook AL and Haynes JM: Phosphorylation of the PKG substrate, vasodilator-stimulated phosphoprotein (VASP), in human cultured prostatic stromal cells. Nitric Oxide 16: 10-17, 2007.

23. Chiche JD, Schlutsmeyer SM, Bloch DB, de la Monte SM, Roberts JD Jr, Filippov G, Janssens SP, Rosenzweig A and Bloch KD: Adenovirus-mediated gene transfer of cGMP-dependent protein kinase increases the sensitivity of cultured vascular smooth muscle cells to the antiproliferative and pro-apoptotic effects of nitric oxide/cGMP. J Biol Chem 273: 34263-34271, 1998.

24. Hood J and Granger HJ: Protein kinase G mediates vascular endothelial growth factor-induced Raf-1 activation and proliferation in human endothelial cells. J Biol Chem 273: 23504-23508, 1998.

25. Swartling FJ, Ferletta M, Kastemar M, Weiss WA and Westermark B: Cyclic GMP-dependent protein kinase II inhibits cell proliferation, Sox 9 expression and Akt phosphorylation in human glioma cell lines. Oncogene 28: 3121-3131, 2009.

26. Yang SQ, Chen YC, Wang Y and Tao Y: Expression of cGMP dependent protein kinase II in cancer cell lines was obviously decreased. J Jiangsu Univ 18: 1-5, 2008 (In Chinese).

27. Chen YC, Ren F, Sang JR, Tao Y and Xu WR: Type II cGMP-dependent protein kinase inhibits proliferation of the gastric cancer cell line BGC-823. Mol Med Rep 3: 361-366, 2010.

28. Chen JC,Zhuang S, Nguyen TH, Boss GR and Pilz RB: Oncogenic Ras leads to Rho activation by activating the mitogen-activated protein kinase pathway and decreasing Rho-GTPase-activating protein activity. J Biol Chem 278: 2807-2818, 2003.

29. Pardo OE, Latigo J, Jeffery RE, et al: The fibroblast growth factor receptor inhibitor PD173074 blocks small cell lung cancer growth in vitro and in vivo. Cancer Res 69: 8645-8651, 2009.

30. Nomura S, Yoshitomi H, Takano S, Shida T, Kobayashi S, Ohtsuka M, Kimura F, Shimizu H, Yoshidome H, Kato A and Miyazaki M: FGF10/FGFR2 signal induces cell migration and invasion in pancreatic cancer. Br J Cancer 99: 305-313, 2008.

31. Chikazu D, Hakeda Y, Ogata N, Nemoto K, Itabashi A, Takato T, Kumegawa M, Nakamura K and Kawaguchi H: Fibroblast growth factor (FGF)-2 directly stimulates mature osteoclast function through activation of FGF receptor 1 and p42/p44 MAP kinase. J Biol Chem 275: 31444-31450, 2000.

32. Brauchle M, Gluck D, Di Padova F, Han J and Gram H: Independent role of p38 and ERK1/2 mitogen-activated kinases in the upregulation of matrix metalloproteinase-1. Exp Cell Res 258: 135-144, 2000 .

33. Tokuda H, Kozawa $\mathrm{O}$ and Uematsu T: Basic fibroblast growth factor stimulates vascular endothelial growth factor release in osteoblasts: divergent regulation by $\mathrm{p} 42 / \mathrm{p} 44$ mitogen-activated protein kinase and p38 mitogen-activated protein kinase. J Bone Miner Res 15: 2371-2379, 2000. 
34. Gonzalez AM, Buscaglia M, Ong M and Baird A: Distribution of basic fibroblast growth factor in the 18-day rat fetus: localization in the basement membranes of diverse tissues. J Cell Biol 110: $753-765,1990$.

35. Folkman J and Klagsbrun M: Angiogenic factors. Science 235: 442-447, 1987.

36. Leung DW, Cachianes G, Kuang WJ, Goeddel DV and Ferrara N: Vascular endothelial growth factor is a secreted angiogenic mitogen. Science 246: 1306-1309, 1989.

37. Ferrara N, Houck K, Jakeman L and Leung DW: Molecular and biological properties of the vascular endothelial growth factor family of proteins. Endocr Rev 13: 18-32, 1992.

38. New BA and Yeoman LC: Identifation of basic firoblast growth factor sensitivity and receptor and ligand expression in human colon tumor cell lines. Cell Physiol 150: 320-326, 1992.

39. Hill CS and Treisman R: Transcriptional regulation by extracellular signals: mechanisms and specificity. Cell 80: 199-211, 1995.

40. Alessi DR, Cuenda A, Cohen P, Dudley DT and Saltiel AR: PD 098059 is a specific inhibitor of the activation of mitogen-activated protein kinase kinase in vitro and in vivo. J Biol Chem 270: 27489-27494, 1995.

41. Francis SH and Corbin JD: Cyclic nucleotide-dependent protein kinases: intracellular receptors for cAMP and cGMP action. Crit Rev Clin Lab Sci 36: 275-328, 1999.

42. Ruth P: Cyclic GMP-dependent protein kinases: understanding in vivo functions by gene targeting. Pharmacol Ther 82: 355-372, 1999.
43. Boerth NJ, Dey NB, Cornwell TL and Lincoln TM: Cyclic GMP-dependent protein kinase regulates vascular smooth muscle cell phenotype. J Vasc Res 34: 245-259, 1997.

44. Sellak H, Yang X, Cao X, Cornwell T, Soff GA and Lincoln T: Spl transcription factor as a molecular target for nitric oxide- and cyclic nucleotide-mediated suppression of cGMP-dependent protein kinase-Ialpha expression in vascular smooth muscle cells. Circ Res 90: 405-412, 2002.

45. Feil R, Hofmann F and Kleppisch T: Function of cGMP-dependent protein kinases in the nervous system. Rev Neurosci 16: 23-41, 2005.

46. Münzel T, Feil R, Mülsch A, Lohmann SM, Hofmann F and Walter U: Physiology and pathophysiology of vascular signaling controlled by guanosine $3^{\prime}, 5^{\prime}$-cyclic monophosphate-dependent protein kinase [corrected]. Circulation 108: 2172-2183, 2003.

47. Schlossmann J, Feil R and Hofmann F: Insights into cGMP signalling derived from cGMP kinase knockout mice. Front Biosci 10: 1279-1289, 2005.

48. Wu Y, Chen Y, Qu R, Lan T and Sang J: Type II cGMP-dependent protein kinase inhibits EGF-triggered signal transduction of the MAPK/ERK-mediated pathway in gastric cancer cells. Oncol Rep 27: 553-558, 2012.

49. Lan T, Chen Y, Sang J, Wu Y, Wang Y, Jiang L and Tao Y: Type II cGMP-dependent protein kinase inhibits EGF-induced MAPK/JNK signal transduction. Oncol Rep 27: 2039-2044, 2012. 